\title{
East Greenland and Faroe-Shetland sediment provenance and Palaeogene sand dispersal systems
}

\author{
Michael Larsen, Christian Knudsen, Dirk Frei, Martina Frei, Thomas Rasmussen and Andrew G.Whitham
}

The sedimentation and basin evolution of the Kangerlussuaq Basin, southern East Greenland has gained renewed interest with the licensing rounds offshore the Faroe Islands in 2000 and 2005, as it forms an important analogy to the Faroese geological setting. The Faroes frontier area is in part covered by basalts and is a high-risk area with poorly known plays and sedimentary basins. It is therefore essential to obtain as much information as possible on the evolution of sedimentary basins on the rifted volcanic margins closest to the Faroese Islands margin. Plate reconstructions of the North Atlantic region indicate the former close proximity of East Greenland to the Faroe Islands region (Fig. 1), and the Kangerlussuaq Basin thus constitutes the most important field analogue with respect to stratigraphy, major unconformities and basin evolution. The study of the sedimentary succession in the Kangerlussuaq Basin, and the provenance of the sandstones in particular, will provide constraints on exploration models and may help to predict the distribution of potential reservoir sandstones in the Faroese offshore basins, and eventually lead to development of play types that are new to this frontier region.
This paper presents the main conclusions from two research projects: Stratigraphy of the pre-basaltic sedimentary succession of the Kangerlussuaq Basin-Volcanic basin of the North Atlantic and An innovative sedimentary provenance analysis, jointly undertaken by the Geological Survey of Denmark and Greenland (GEUS) and CASP (formerly Cambridge Arctic Shelf Programme). Both projects were initiated in October 2002 and concluded in September 2005. They form part of Future Exploration Issues Programme of the Faroese Continental Shelf (SINDRI programme), established by the Faroese Ministry of Petroleum and financed by the partners of the Sindri Group (see Acknowledgements).

\section{Cretaceous-Palaeogene stratigraphy}

Field work in the 1990s and results from the present projects require revision of the existing lithostratigraphic schemes for the pre-basaltic succession in the Kangerlussuaq Basin. Several hitherto unknown units have been discovered, and a new detailed biostratigraphy has been established incorporating

\footnotetext{
Greenland geology

Palaeogene basalts

Cretaceous-Palaeogene sediments

Crystalline basement

Ice

-... International boundary

Sediment input

- Well with provenance study

- Faroese exploration wells
}

Fig. 1. Map showing the location of the Kangerlussuaq Basin relative to the Faroe Islands and the Faroe-Shetland Basin before the opening of the North Atlantic. The provenance study was carried out on samples from the Kangerlussuaq Basin, East Greenland and from the UK exploration wells marked on the map. Arrows indicate the three characteristic sediment provenance areas identified in the provenance study. Also shown are the three exploration wells drilled in Faroese waters.

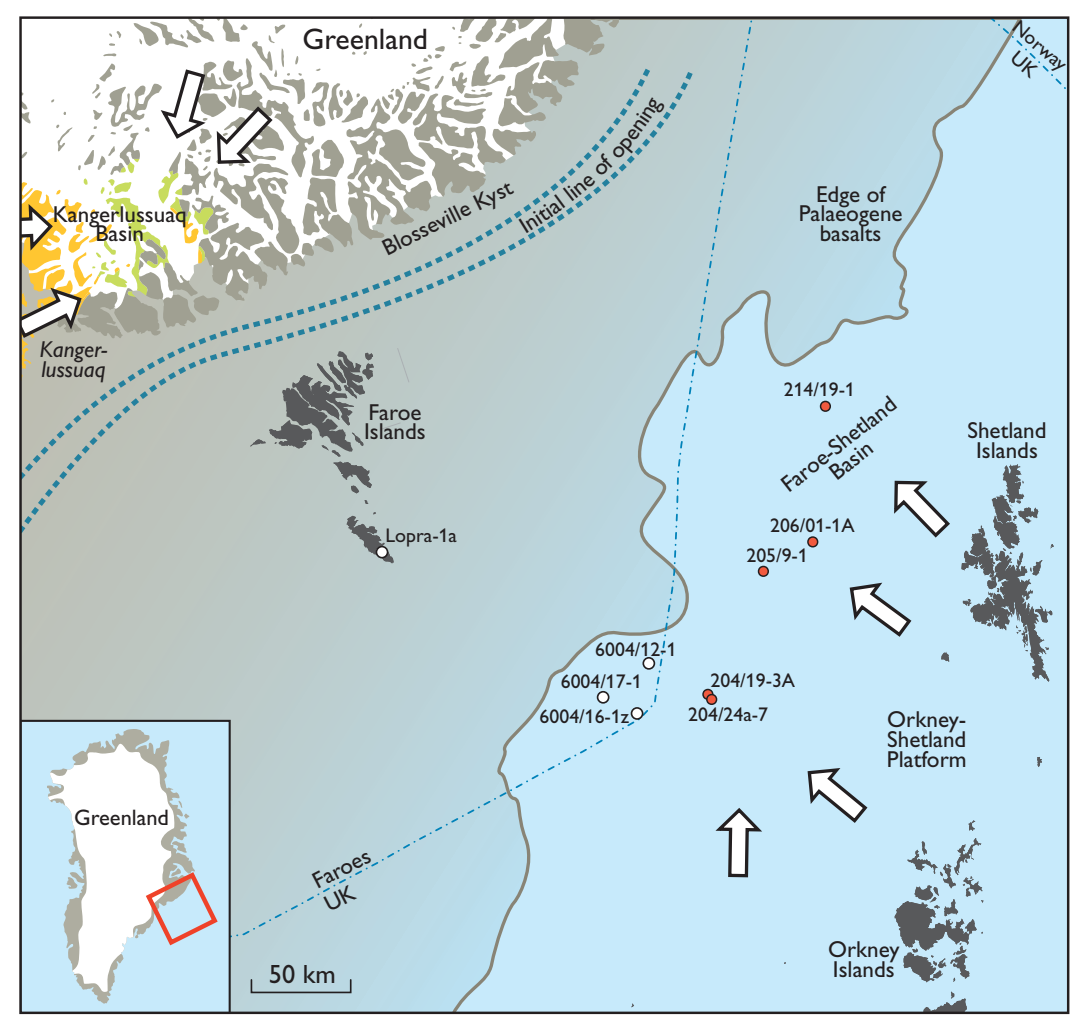


age revisions based on both macrofossils and palynomorphs (Fig. 2; Larsen et al. 1999, 2001). The new biostratigraphy allows close correlation with the sub-basaltic successions in the offshore basins west of Shetland and in the Faroe Islands region. Most striking is the presence in both the Kangerlussuaq Basin and the Faroe-Shetland Basin of a Lower Cretaceous shallow marine sandstone unit as well as a number of thick Paleocene units dominated by sandstones. For the provenance study six sedimentary units were established (Fig. 2). The first four of these are Cretaceous; the Palaeogene units 5 and 6 are discussed below.

In the Kangerlussuaq Basin several regional subaerial unconformities representing sequence boundaries indicate times of sediment erosion and bypass. Based on field work a

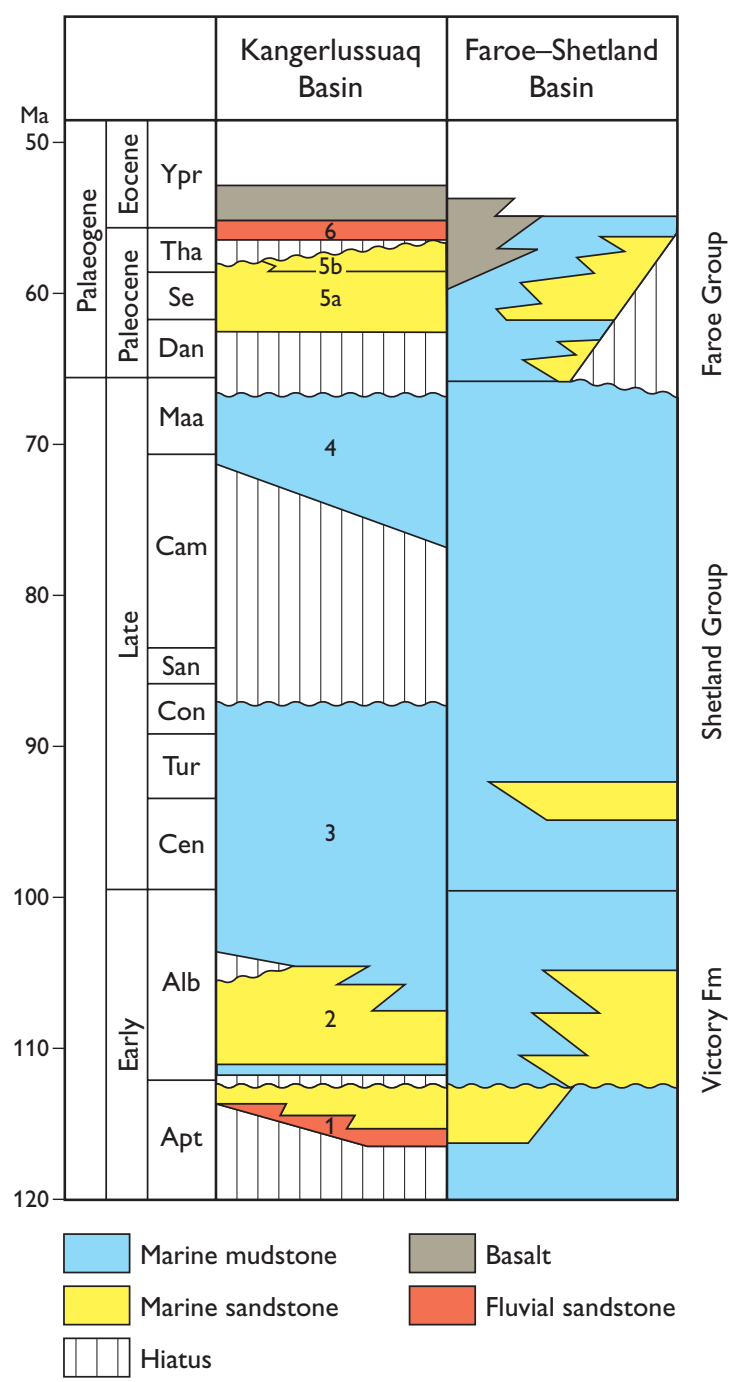

Fig. 2. Revised stratigraphy of the pre-basaltic succession in the Kangerlussuaq Basin. A formal lithostratigraphic scheme including names for new formations and members is in preparation. A composite stratigraphy of the Faroe-Shetland Basin is shown for comparison (from Grant et al 1999; Ellis et al. 2002). Numbers 1-6 refer to units samples for detrital zircon studies (see Fig. 4). depositional model for the Kangerlussuaq Basin has been established and prediction of reservoir sandstones in offshore basins can be carried out.

\section{Palaeogene sandstones of the Kangerlussuaq Basin}

The Early Palaeogene succession in the Kangerlussuaq Basin consists of three distinct sandy units labelled $5 \mathrm{a}, 5 \mathrm{~b}$ and 6 (Fig. 2), which represent different depositional environments. Graded thin-bedded sandstones dominate the lowest unit (5a); the sandstones are laterally consistent and may form amalgamated units up to $20 \mathrm{~m}$ thick. They were deposited in a deep marine environment and represent Selandian turbidite channel-fill and distal submarine fan lobes (Larsen et al. 1999). The next unit (5b) consists of well-sorted fine- to medium-grained sandstones showing hummocky cross-stratification and wave ripples. The sandstones are bioturbated showing traces of Ophimorpha isp. and Thallasoinoides isp. The unit forms an overall coarsening upward succession and is interpreted as deposited by shallow marine sand-bars and deltaic mouth-bars. A major erosional unconformity separates the second unit from coarse-grained and pebbly sandstones of the overlying unit 6 . The sandstones show large-scale trough cross-bedding and contain fragments of coal and coalified wood. Unit 6 represents fluvial sandstones deposited in a proximal braided river system (Fig. 3).

\section{Sandstone provenance}

Provenance studies of sediments in the Faroe-Shetland Basin, on the Orkney-Shetland Platform and in the Kangerlussuaq Basin, East Greenland have been carried out using both analysis of bulk geochemical composition of the sediments and age determinations of detrital zircons.

Bulk geochemical analysis was carried out at GEUS on a total of 440 samples. Of these, 171 samples were collected from the Cretaceous, Paleocene and Eocene sedimentary rocks in the Kangerlussuaq Basin, while 269 represent Paleocene and Eocene sediments selected from cutting samples from wells in the Faroe-Shetland Basin. In each sample, major elements were analysed by fusion wavelength dispersive X-ray fluorescence (WD-XRF) and 33 trace elements by fusion inductively coupled plasma mass spectroscopy (ICPMS). The analytical results provide distinctive geochemical signatures for the various units of the Kangerlussuaq Basin and the Faroe-Shetland Basin. Thus, Selandian marine turbiditic sandstones in the Kangerlussuaq Basin can be shown to be derived from beach placer deposits; their high $\mathrm{Zr}$ contents and characteristic U/REE ratios are indicative of a high heavy mineral content. This is in contrast to marine Selan- 
dian sediments of the Faroe-Shetland Basin, where comparable $\mathrm{Zr}$ and U/REE patterns are lacking, suggesting that the Selandian marine sandstones in the Kangerlussuaq Basin and the Faroe-Shetland Basin have different sources.

\section{Age determinations of detrital zircon}

During the present study a total of 4347 detrital zircon grains from 47 samples were dated. The samples were from three locations: 25 from the Kangerlussuaq Basin, 20 from the Faroe-Shetland Basin and two from outcrops of Old Red Sandstone on the Orkney Islands. The analyses were carried out at GEUS using a laser ablation inductively coupled plasma mass spectrometer (LA-ICP-MS, Quadrupole), with in situ determination of the ${ }^{207} \mathrm{~Pb} /{ }^{206} \mathrm{~Pb}$ isotopic ratios. Frei et al. (2006, this volume) have compared ages obtained by U-Pb dating using both conventional SHRIMP and high resolution sector field LA-ICP-MS (HR-SF-LA-ICP-MS) methods and demonstrated that the $\mathrm{Pb} / \mathrm{Pb}$ dating based on ${ }^{207} \mathrm{~Pb} /$ ${ }^{206} \mathrm{~Pb}$ isotopic ratios determined by LA-ICP-MS is a reliable method for determining detrital zircon age distributions.

The observed distribution of zircon ages clearly shows that there are two distinct sources of detrital grains in the Kangerlussuaq Basin (Fig. 1). The Lower Cretaceous sedimentary rocks in the basin (units 1-3, Figs 2, 4) contain dominantly Neoarchaean and Mesoarchaean detrital zircons. The Upper Cretaceous sediments, however, contain a significant proportion of Proterozoic detrital zircons (unit 4, Figs $2,4)$. The Paleocene marine sandstones are characterised by a large proportion of Archaean grains and variable proportions of Proterozoic zircons (unit 5, Figs 2, 4). The fluvial deposits of unit 6 (Figs 2, 4) contain mainly Archaean detrital zircons and very few Proterozoic detrital zircons.

Known possible sources of Archaean zircons are the Archaean basement gneisses south and south-west of Kangerlussuaq. The most probable sources of Proterozoic zircons are to the north, where the Caledonian orogenic belt exposes extensive areas of Proterozoic granites and gneisses, as well as Archaean gneiss complexes. It can be argued that units 1-3 and 6 received their main sediment input from the south, unit 4 from the north, while unit 5 may have had input from both north and south.

The samples analysed from the Faroe-Shetland Basin range in age from Early Paleocene to Early Eocene. The detrital zircon age distributions are similar in all analysed samples (not illustrated here), and include both Proterozoic and Archaean zircons. The Proterozoic zircons exhibit a wide age distribution from Neo- to Palaeoproterozoic, whereas the Archaean zircons all fall in a narrow cluster from 2550 to $2950 \mathrm{Ma}$, with a peak around $2800 \mathrm{Ma}$. The almost complete absence of Mesoarchaean zircons compared to the

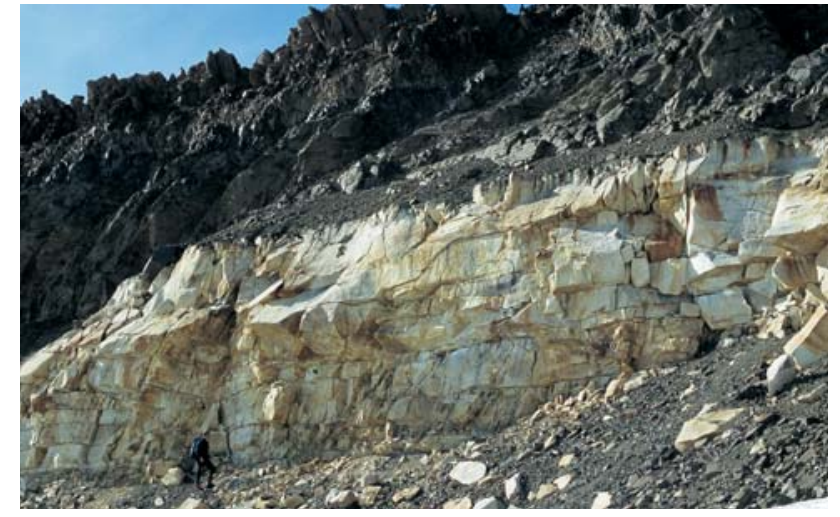

Fig. 3. The Paleocene of the Kangerlussuaq area is characterised by siliciclastic sandstone units deposited by prograding shallow marine and deltaic systems. The photograph shows fine-grained, pale sandstones (unit 6, Fig. 2) overlain by dark brown volcanic deposits (tuffs and lavas). Person (lower left) for scale.
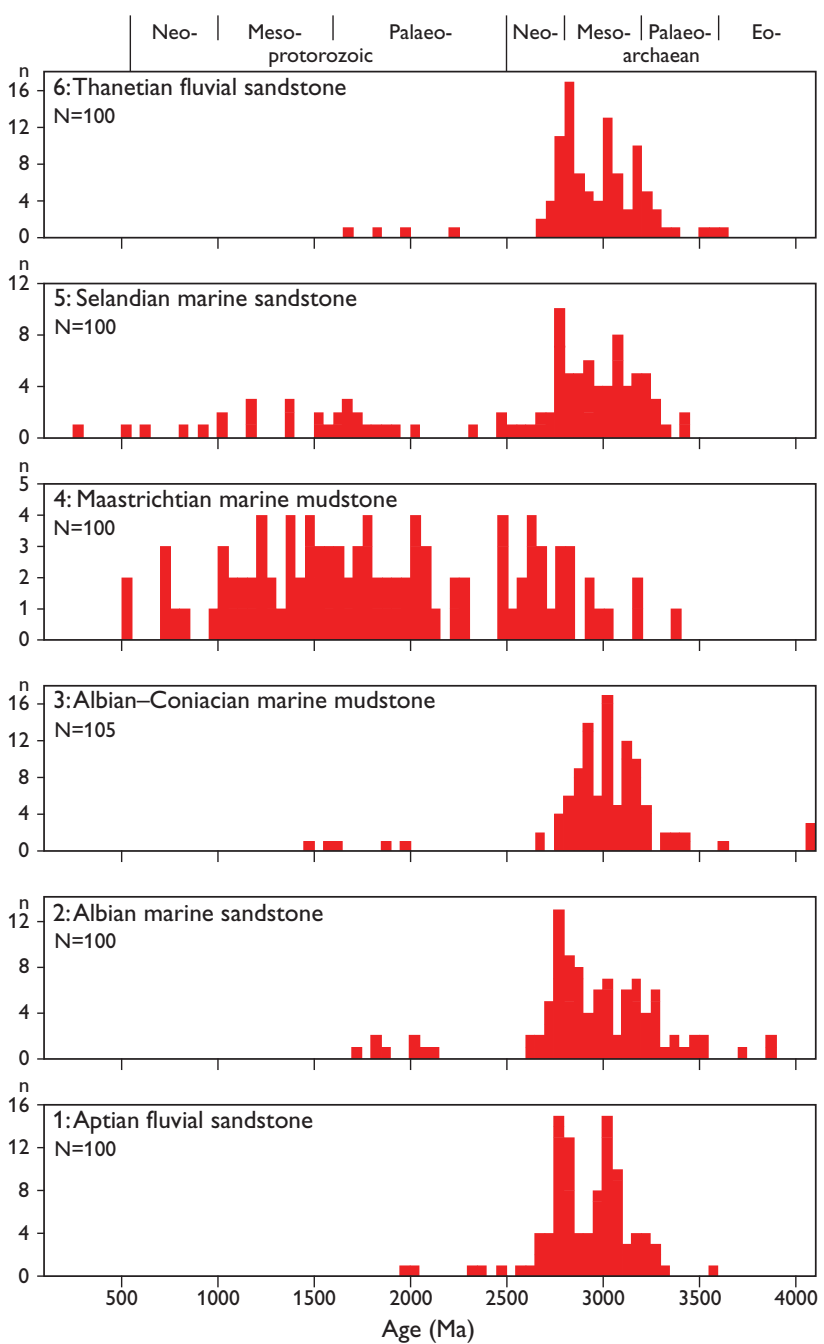

Fig. 4. Age distribution of detrital zircons from six units of the Kangerlussuaq Basin. $\mathbf{N}$, number of analyses; $\mathbf{n}$, sample frequency. Note vertical scale varies from unit to unit. For stratigraphic position of samples, see Fig. 2. 
Kangerlussuaq Basin suggests that the sandstones from the Kangerlussuaq basin and the wells we have studied in the Faroe-Shetland Basin were sourced from different areas.

\section{Greenland sands in offshore basins?}

It was noted by Larsen et al. (1999) that the Cretaceous Early Palaeogene evolution of the Kangerlussuaq Basin is similar to the eastern margin of the Faroe-Shetland Basin (Fig. 2). Ziska \& Andersen (2005) stressed the apparent symmetrical development of the Faroe-Shetland Basin and thus the possibility of locating reservoir units below the basalts on the Faroe Islands side of the basin, similar to those already identified on the United Kingdom side. Sandstone provenance studies provide a possible means of testing the hypothesis that the Kangerlussuaq region provided sediment to the south-western end of the Faroe-Shetland Basin. The only Paleocene sand units in the basin so far recognised as having a western source are found in well 205/9-1 (Lamers \& Carmichael 1999), but these units do not have heavy mineral characteristics compatible with an origin from the Kangerlussuaq region (Whitham et al. 2004). Recent studies by Jolley et al. (2005), based on pollen frequency data, suggest that sediments derived from Greenland are present in several wells of the Faroe-Shetland Basin. Sediment input from Greenland is related to periods of low relative sea level in the Palaeogene and appear to be focused along sediment transfer zones, e.g. the Westray and Judd transfer zones (Larsen \& Whitham 2005). The provenance study of sandstones from the Kangerlussuaq Basin demonstrates that sandstones and mudstones show stratigraphic variations that are related to major sequence boundaries. Furthermore, these sands show distinctive characteristics, particularly in the age distribution of detrital zircons, suggesting that they may be differentiated from sands derived from the north-west European margin (Whitham et al. 2004). Further studies from wells on the western part of the Faroe-Shetland Basin and newer, not yet released data from wells drilled in Faroese waters may provide the final evidence for the Palaeogene sand dispersal systems discussed here.

\section{Acknowledgements}

The companies of the Sindri Group are gratefully acknowledged for their financial support of the two projects and field work in the Kangerlussuaq Basin, southern East Greenland in 2004. The Sindri Group comprises
Agip Denmark BV, Amerada Hess (Faroes) Ltd., Anadarko Faroes Company, P/F Atlantic Petroleum, BP Amoco Exploration Faroes Ltd., British Gas International BV, DONG Føroyar P/F, Enterprise Oil Exploration Ltd., Føroya Kolvetni P/F, Petro-Canada Faroes GmbH, Phillips Petroleum Europe Exploration Ltd., Shell (UK) Ltd. and Statoil Færøyene AS.

\section{References}

Ellis, D., Bell, B.R., Jolley, D.W. \& O'Callaghan, M. 2002: The stratigraphy, environment of eruption and age of the Faroes Lava Group, NE Atlantic: In: Jolley, D.W. \& Bell, B.R. (eds): The North Atlantic Igneous Province. Stratigraphy, tectonic, volcanic and magmatic processes. Geological Society (London) Special Publications 197, 253-269.

Frei, D., Hollis, J.A., Gerdes, A., Harlov, D., Karlsson, C., Vasquez, P., Franz, G., Johansson, L. \& Knudsen, C. 2006: Advanced in situ geochronological and trace element microanalysis by laser ablation techniques. Geological Survey of Denmark and Greenland Bulletin 10, $25-28$.

Grant, N., Bouma, N. \& McIntyre, A. 1999: The Turonian play in the Faeroe-Shetland Basin. In: Fleet, A.J. \& Boldy, S.A.R. (eds): Petroleum geology of Northwest Europe: Proceedings of the 5th Conference, 661-673. London: Geological Society.

Jolley, D.W., Morton, A. \& Prince, I. 2005: Volcanogenic impact on phytogeography and sediment dispersal patterns in the northeast Atlantic. In: Doré, A.G. \& Vining, B. (eds): Petroleum geology: North-West Europe and global perspectives - Proceedings of the 6th Petroleum Geology Conference, 969-975. London: Geological Society.

Lamers, E. \& Carmichael, S.M.M. 1999: The Paleocene deepwater sandstone play West of Shetland. In: Fleet, A.J. \& Boldy, S.A.R. (eds): Petroleum geology of Northwest Europe: Proceedings of the 5th Conference, 645-659. London: Geological Society.

Larsen, M. \& Whitham, A.G. 2005: Evidence for a major sediment input point into the Faroe-Shetland Basin from the Kangerlussuaq region of southern East Greenland. In: Doré, A. \& Vining, B. (eds): Petroleum geology: North-West Europe and global perspectives - Proceedings of the 6th Petroleum Geology Conference, 913-922. London: Geological Society.

Larsen, M., Hamberg, L., Olaussen, S., Nørgaard-Pedersen, N. \& Stemmerik, L. 1999: Basin evolution in southern East Greenland: an outcrop analog for the Cretaceous-Paleogene basins on the North Atlantic volcanic margin. American Association of Petroleum Geologists Bulletin 83, 1236-1261.

Larsen, M., Bjerager, M., Nedkvitne, T., Olaussen, S. \& Preuss, T. 2001: Pre-basaltic sediments (Aptian-Paleocene) of the Kangerlussuaq Basin, southern East Greenland. Geology of Greenland Survey Bulletin 189, 99-106.

Whitham, A.G., Morton, A.C. \& Fanning, C.M. 2004: Insights into Cretaceous-Paleocene sediment transport paths and basin evolution in the North Atlantic from a heavy mineral study of sandstones from southern East Greenland. Petroleum Geoscience 10, 61-72.

Ziska, H. \& Andersen, C. 2005: Exploration opportunities in the Faroe Islands. In: Ziska, H., Warming, T. \& Bloch, D. (eds): Faroe Islands exploration conference: Proceedings of the 1st conference. Annales Societatis Scientiarum Færoensis Supplementum 43, 146-162.

\section{Authors' address}

M.L.,Geological Survey of Denmark and Greenland, Øster Voldgade 10, DK-1350 Copenhagen K, Denmark. Present address: DONG Energy, Agern Alle 24-26, DK-2970 Hørsholm, Denmark.

C.K., D.F., M.F. \& T.R., Geological Survey of Denmark and Greenland, Øster Voldgade 10, DK-1350 Copenhagen K, Denmark. E-mail: ckn@geus.dk A.G.W., CASP, Department of Earth Sciences, University of Cambridge, West Building, 181a Huntingdon Road, Cambridge, CB3 ODH, UK. 